\title{
Contrastive and Integrated Teaching Application of Effective Interest Method*
}

\author{
Yi Tang \\ Guangdong University of Science and Technology \\ Dongguan, China 523083
}

\author{
Mengyuan Liu \\ Guangdong University of Science and Technology \\ Dongguan, China 523083
}

\begin{abstract}
At present, effective interest method is extensively used in confirmation of effective yield (or expense) during the holding of fixed or ascertainable assets (or liabilities) of future cash flows. It uses initial amortized cost to multiply by effective interest rate, in order to determine effective yield of current period, and then determine amortization amount of amortization items of current period. It's difficult for students to understand and accept the method. Taking accounting treatment of financial assets and corresponding financial liabilities as example to carry out contrastive and integrated teaching can make students digest and save class hour as well as greatly improve teaching effectiveness and efficiency. The research provides important reference for daily practical teaching of effective interest method.
\end{abstract}

Keywords-effective interest method; amortized cost; contrastive; integrated; teaching

\section{INTRODUCTION}

Article 14 of No. 22 Accounting Standards for Business Enterprises-Confirmation and Measurement of Financial Instruments (No. 22 ASBE for short) (Feb. 15, 2006) proposes: effective interest method calculates amortized cost, interest income or interest expenses in each period according to effective interest rate of financial assets or financial liabilities. Effective interest rate refers to the rate used in discounting future cash flows of financial assets or financial liabilities in expected duration or applicable shorter period to the current book value of financial assets or financial liabilities.

Effective interest method is a distinctly important method in accounting practice. At present, it is widely used in amortization of premium and discount of financial assets (liabilities) and accounting of selling goods through collection by installment, purchasing assets through payment by installment, finance lease. It's difficult for students to learn and understand the method, let alone flexible application of it. Therefore, it is necessary to discuss the method and better apply it to teaching practice, in order to improve students' learning effectiveness and efficiency.

\section{ANALYSIS ON CONNOTATION OF EFFECTIVE INTEREST METHOD}

Effective interest method calculates and confirms

*Fund project: This paper is the phased research result of Guangdong university provincial level major scientific research project (2015GXJK163 effective interest at each period during the holding of financial assets (liabilities) according to effective interest rate. In this method, first, we must calculate effective interest rate, namely, the current value of future cash flow of financial assets (liabilities) is equal to discount rate of current book value. We need to calculate coupon payments (face value multiplies by coupon rate), effective interest (initial amortized cost multiplies by effective interest rate). The balance of the two is the amortization amount of amortization item at current period. In order to learn effective interest method, the understanding and calculation of amortized cost is of vital importance. Article 13 of No. 22 ASBE gives detailed explanation: amortized cost of financial assets or financial liabilities refers to the results that the initial confirmed amount of financial asset or financial liability goes through the following adjustment: (1) deduct the principal paid; (2) plus or minus accumulated amortization amount after amortizing the balance between initial confirmed amount and amount at maturity date through effective interest method; (3) deduct impairment loss occurred (only applicable to financial assets). In short, amortized cost is equal to initial confirmed amount (cost plus debit balance of amortization account) minus principal paid minus accumulated amortization amount of amortization account in credit minus impairment loss occurred; or amortized cost is equal to initial confirmed amount (cost minus credit balance of amortization account) minus principal paid plus accumulated amortization amount of amortization account in debtor minus impairment loss occurred. If it is the financial instrument of accrual debt at maturity, the above calculation formulas should add cumulative number of "accrued interest". But the last period of holding period uses "backwards method" to avoid "calculation end difference". First calculate nominal interest (coupon interest) and then calculate balance of amortization account and amortize the surplus. The effective interest of last period is equal to nominal interest plus or minus the last amortization amount of amortization account.

\section{COMPARATIVE AND INTEGRATED TEACHING APPLICATION OF EFFECTIVE INTEREST METHOD}

In regard to financial instruments, the holder regards it as financial assets but the issuer regards it as financial liabilities. It is easy to contrast financial assets and financial liabilities, so we can carry out contrastive and integrated application in 
teaching. Held-to-maturity investment is non-current asset, while bonds payable are non-current liability. They are important parts of financial accounting course. They have strong contrast. Teaching through contrasting and integrating held-to-maturity investment and accounting treatment of bonds payable avails the understanding and application of effective interest method. The contrast of them is shown in table 1. Article 11 of No.22 ASBEL: Held-to-maturity investment refers to ascertainable non-derivative financial asset with fixed maturity date and fixed recovery amount that enterprises have clear intention and ability to hold to maturity when obtaining it. Bonds payable refer to securities above maturity of one year that enterprises issue in accordance with legal procedures and agree to repay capital and interest within a certain period. Next, classical examples will be provided to explain the application of effective interest method in teaching through contrasting and integrating held-to-maturity investment and bonds payable.

TABLE I. CONTRAST OF HELD-TO-MATURITY INVESTMENT AND BONDS PAYABLE

\begin{tabular}{|c|c|c|}
\hline & $\begin{array}{c}\text { held-to-maturity } \\
\text { investment }\end{array}$ & bonds payable \\
\hline $\begin{array}{l}\text { Long-term } \\
\text { item }\end{array}$ & Non-current asset & Non-current liability \\
\hline $\begin{array}{l}\text { Financial } \\
\text { item }\end{array}$ & Financial asset & Financial liability \\
\hline \multirow{3}{*}{$\begin{array}{l}\text { Need to set } \\
\text { detailed } \\
\text { account }\end{array}$} & Cost & Face value \\
\hline & Interest adjustment & Interest adjustment \\
\hline & Accrued interest & Accrued interest \\
\hline $\begin{array}{l}\text { Subsequent } \\
\text { interest } \\
\text { treatment } \\
\text { uses } \\
\text { effective } \\
\text { interest } \\
\text { method }\end{array}$ & $\begin{array}{l}\text { Accounting entry: } \\
\text { Debit: accrued interest } \\
\text { (bullet repayment of } \\
\text { interest at maturity) or } \\
\text { interest receivable } \\
\text { (installment interest } \\
\text { payment) } \\
\text { Credit: income from } \\
\text { investment (effective } \\
\text { interest) } \\
\text { Interest adjustment } \\
\text { amortization (or credit) }\end{array}$ & $\begin{array}{l}\text { Accounting entry: } \\
\text { Debit: financial expense } \\
\text { (effective interest) } \\
\text { Interest adjustment } \\
\text { amortization (or credit) } \\
\text { Credit: accrued interest (lump } \\
\text { sum withdrawal of interest at } \\
\text { maturity) or interest payable } \\
\text { (installment interest payment) }\end{array}$ \\
\hline $\begin{array}{l}\text { Principal } \\
\text { treatment at } \\
\text { maturity }\end{array}$ & Withdraw principal & Pay principal \\
\hline
\end{tabular}

E.g. 1: On January 1, 2008, X Company spends 10 billion yuan in purchasing five-year bond issued by $\mathrm{Y}$ Company on the same day from active market, with face value of 12.5 million yuan and nominal annual interest rate of 4.72 percent. Charge interests annually and carry out lump sum withdrawal of capital. When purchasing the bond, X Company has intention and ability to hold it at maturity, predicting Y Company will not redeem in advance. Suppose the effective interest rate is 10 percent when purchasing, without regard to impairment loss, how X Company to carry out accounting treatment (unit: ten thousand yuan):

(1) On January 1, 2008, when purchasing bond: debit: held-to-maturity investment-cost 1,250, credit: deposit in bank 1,000, held-to-maturity investment-interest adjustment 250;

(2) The first four years (2008-2011) uses effective interest method

a). Calculate amortization amounts of effective interest income and interest adjustment:

Annual nominal interest (coupon interest) $=1250 * 4.72 \%=59$

2008:[1250-250]*10\%=100;100-59=41.

2009:[1250- (250-41) ]*10\%=104.1; 104.1-59=45.1.

2010:[1250- (250-41-45.1) ]*10\% =108.61；108.61$59=49.61$

2011:[1250- (250-41-45.1-49.61) ]*10\%=113.56 ; $113.56-59=54.65$.

b). Accounting entry of interest treatment in the end of each year from 2008 to 2011 :

2008200920102011

Debit: interest receivable $\quad \begin{array}{llll}59 & 59 & 59 & 59\end{array}$

Held-to-maturity investment - interest adjustment

$41 \quad 45.1 \quad 49.61 \quad 54.56$

Credit: income from investment $100 \quad 104.1 \quad 108.61$ 113.56

When receiving interest in the end of the year, debit: deposit in bank 59, credit: interest receivable 59

(3) Accounting entry of interest treatment in 2012 (the last year):

Debit: interest receivable 59, held-to-maturity investment-interest adjustment $59.72 \quad(=250-41-45.1$ 49.61- 54.561, namely amortize the surplus), credit: Income from investment 118.72 (backwards); meanwhile, debit: deposit in bank 1,309, credit: interest receivable 59, held-to-maturity investment-cost 1,250

E.g.2: According to example 1, Y Company issued at a discount on January 1, 2008 and got revenue of issue of 10 million yuan. Suppose the funds collected through issuing bonds are used to construct a production line (begin on January 1, 2008 and complete in the end of 2012, reach the serviceable condition), predicting it will not redeem in advance. How Y Company to compile the accounting entry of issuing bonds and annual interest expense at maturity:

(1) On January 1, 2008, when issuing bond: debit: deposit in bank 1,000, bonds payable-interest adjustment 250, credit: bonds payable - face value 1,250

(2) The first four years (2008-2011) uses effective interest method

a): Calculate amortization amounts of effective interest income and interest adjustment: 
Annual nominal interest (coupon interest) $=1250 * 4.72 \%=59$

2008:[1250-250]*10\%=100;100-59=41.

2009:[1250- (250-41) ]*10\%=104.1; 104.1-59=45.1.

2010:[1250- (250-41-45.1) ]*10\%=108.61 ; 108.61$59=49.61$.

2011:[1250- (250-41-45.1-49.61) ]*10\%=113.56 ; $113.56-59=54.65$

b): Accounting treatment on interest in the end of each year from 2008 to 2011:

2008200920102011

Debit: project under construction $100 \quad 104.1 \quad 108.61$ 113.56

Credit: interest payable $\quad \begin{array}{llll}59 & 59 & 59 & 59\end{array}$ 54.56

Bonds payable-interest adjustment $4145.1 \quad 49.61$

When receiving interest, debit: interest payable 59, credit: deposit in bank 59

(3) 2012 (the last year):

a): Accounting entry of interest treatment, debit: project under construction 118.72 (backwards), credit: interest payable 59, bonds payable - interest adjustment 59.72 (25041-45.1-49.61-54.571, namely amortize the surplus)

b): In repayment of principal at maturity, debit: bonds payable-face value 1,250, interest payable 59, credit: deposit in bank 1,309

It is easy to contrast held-to-maturity investment and bonds payable. It proves that it is effective to carry out contrastive teaching through designing the above classical examples, integrate effective interest method and guide students to learn through contrast, digest and expand thinking.

\section{CONCLUSION}

To sum up, effective interest method uses initial amortized cost to multiply by effective interest rate to calculate effective interest of current period, and uses effective interest to calculate amortization amount of amortization items. It is specific application of time value of money and important method of interest calculation in financial accounting. It is feasible to teach through contrasting and integrating issuer and investor of long-term debt instrument in bullet payment of principal and interest, selling goods through installation long-term collection and purchasing assets through installation long-term payment, leaser and tenant in finance lease, long-term debit and credit. It helps students to understand effective interest method and the accounting treatment of assets and liabilities and saves class hour, in order to achieve better teaching effectiveness and efficiency. Therefore, the research provides important references for daily practical teaching of effective interest method.

\section{REFERENCES}

[1] Song Aihua. Application of Effective Interest Method in Accounting Practice $[\mathrm{J}]$, Communication of Finance and Accounting, 2010(22)

[2] Deng Xueya, Jiang Xin. Comprehensive Analysis and Application of Effective Interest Method and Amortized Cost [J], Commercial Accounting, 2013(03)

[3] Liang Haiguang, Wang Yan, Wang Rufeng. Visual Explanation on Follow-up Measurement of Financial Liability through Amortized Cost: Take Bonds Payable as an Example [J], Finance and Accounting Monthly, 2016(19)

[4] Deng Lunhui. Discussion on Effective Interest Method [J], Communication of Finance and Accounting, 2013(31)

[5] Hu Zhimin. Discussion on Teaching Reform of Effective Interest Method [J], Communication of Finance and Accounting, 2011(28)

[6] No. 22 Accounting Standards for Business Enterprises, Confirmation and Measurement of Financial Instruments [J], Finance and Accounting Monthly, 2006(19)

[7] Jia Chenghai. Opinions on Accounting Treatment of Long-term Bond Investments: Discussion on No. 22 Accounting Standards for Business Enterprises, Confirmation and Measurement of Financial Instruments [J], Finance and Accounting Monthly, 2015(19)

[8] Zhao Junmei, Shang Jin. Discussion on Accrual Bond Measurement in Held-to-maturity Investment [J], Finance and Accounting Monthly, 2014(07)

[9] Xu Xueying. Comparison between Available-for-sale Financial Assets and Held-to-maturity Investment [J], China Township Enterprises Accounting, 2009(09)

[10] Li Xiao. Selection and Comparison of Measurement Attribution of Financial Instruments [J], Cooperative Economy and Science, 2012(07) 